\title{
PARTICULARITIES IN CARDIOVASCULAR RECOVERY BY PHYSICAL TRAINING IN A PATIENT WITH PROSTHETIC VALVE, PERMANENT ELECTRICAL CARDIAC STIMULATION AND AORTOCORONARY BYPASS
}

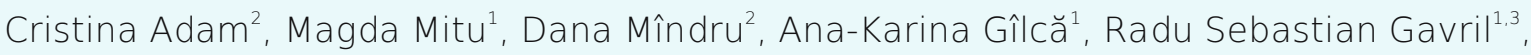 \\ Mihai Roca ${ }^{1,3}$, Florin Mitu ${ }^{1.3}$ \\ ${ }^{1}$ Recovery Clinic Hospital, Cardiovascular Rehabilitation Iași \\ ${ }^{2}$ Cardiovascular Institute "Prof. Dr. George. I. M. Georgescu" Iași \\ ${ }^{3}$ "Grigore T. Popa" University of Medicine and Pharmacy, Iaşi
}

Corresponding author: Cristina Adam

Recovery Clinic Hospital, Cardiovascular Rehabilitation Iași

e-mail: adam.cristina93@gmail.com

\begin{abstract}
:
Introduction: Going through a complete cardiac rehabilitation is essential for all cardiac patients undergoing complex surgery, including those who wear intracardiac devices. Determining the effort capacity after the surgical intervention might provide satisfactory results with the improvement of the quality of life.
\end{abstract}

Case presentation: We present the case of a male patient, 44 years old, known with aortic bicuspid valve, aortic mechanical valve evolved with prosthesis mismatch and aortocoronary bypass (right coronary artery), followed by total atrioventricular block which required cardiac pacemaker VVI, who is admitted in the Cardiovascular Rehabilitation Clinic to continue the second phase of the rehabilitation program. The ergospirometry test (which was performed in order to evaluate the impairment of the effort capacity) showed a moderate-severe decrease of effort capacity (42\% of maximal oxygen consumption, class C Weber), effort hypotension and chronotropic incompetence which led to pausing cardiopulmonary test before anaerobic threshold. Stepper exercise or climbing stairs did not cause the lowering of blood pressure and heart rate, which led to the idea of controlling and adjusting the stimulation parameters. Within cardiopulmonary testing in patients with pacemaker special regards should be paid towards: parameters assessment during effort (heart rate during the test in pacemakers without adaptation to exercise, heart rate during the test in pacemakers with adaptation to exercise, evaluation of the effort response in patients undergoing resynchronization therapy) and diagnosis of exercise-induced arrhythmia (atrial fibrillation, ventricular extrasystoles, ventricular tachycardia, as well as identification of arrhythmias in patients with implantable cardioverter defibrillator). 


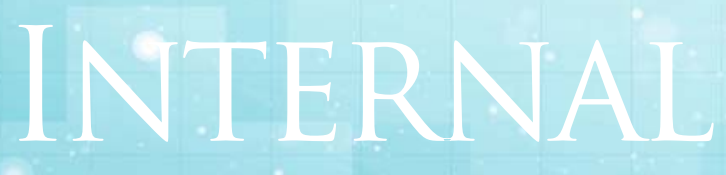

Clinical cases

Conclusion: The cardiopulmonary stress test in patients with cardiostimulation should respect certain conditions in conducting the test in order to obtain realistic results of functional capacity. Due to the position of the piezoelectric crystal and the immobilization of the limbs during the cycle ergometer test it is recommended testing using the treadmill.

Key words: ergospirometry, cardiostimulation, prosthesis, recovery, bypass

\section{Rezumat}

Introducere: Parcurgerea unui program complet de recuperare cardiovasculară este esenţială pentru toţi pacienţii cardiaci, supuşi unor intervenţii chirurgicale complexe, inclusiv la cei purtători de dispozitive intracardiace. Determinarea capacităţii de efort după etapa chirurgicală asigură premisa unui rezultat satisfăcător, cu ameliorarea calităţii vieţii.

Prezentarea cazului: Prezentǎm cazul unui pacient de sex masculin, în vârstă de 44 de ani, cunoscut cu bicuspidie aortică, proteză mecanică valvulară aortică, în evoluţie cu mismatch de proteză şi by-pass aortocoronarian la nivelul arterei coronare drepte, urmat de apariţia unui bloc atrio-ventricular total ce a necesitat cardiostimulare electrică permanentă de tip VVI, se prezintă în Clinica de Recuperare Cardiovasculară în vederea continuării celei de-a doua faze a programului de recuperare, asociind un sindrom anemic post-chirurgical. La testarea ergospirometrică (efectuată în scop prognostic şi pentru aprecierea obiectivă a alterării capacităţii de efort) s-a constatat o diminuare moderat-severă a acesteia (42\% din consumul maxim de oxigen, clasa C Weber), cu apariţia hipotensiunii la efort şi a incompetenţei cronotrope, ceea ce a determinat întreruperea testului cardiopulmonar înainte de atingerea pragului anaerob. Exerciţiul fizic la stepper sau urcatul scărilor nu au scăzut tensiunea arterială şi frecvenţa cardiacă, fapt ce aduce în discuţie controlul şi ajustarea parametrilor de stimulare. În cadrul testării cardiopulmonare la purtătorii de pacemaker trebuie acordată o atenție deosebită la două aspecte: - evaluarea parametrilor de stimulare la efort (FC în timpul testului în cazul stimulatoarelor fără adaptare la efort, FC în timpul testului în cazul stimulatoarelor cu adaptare la efort, evaluarea răspunsului la efort în cazul pacientilor supusi terapiei de resincronizare cardiacă) și - diagnosticul aritmiilor induse de efort (fibrilație atrială, extrasistole ventriculare, tahicardie ventriculară, precum și identificarea aritmiilor la pacienții cu ICD).

Concluzii: în fața unui pacient cardiostimulat supus testului de efort cardiopulmonar, sunt importante condițiile de efectuare ale testului pentru a obține rezultate reale ale capacității funcționale -> datorita pozitiei cristalului piezoelectric și imobilizarea membrelor în timpul testului la cicloergometru, se recomandă testarea cu ajutorul covorului rulant.

Cuvinte cheie: ergospirometrie, cardiostimulare, proteză, recuperare, by-pass 


\section{INTRODUCTION}

Cardiovascular recovery is an essential component in the treatment of patients with associated cardiac pathologies, being recommended for the improvement of the functional capacity, the adaptation to the psychological changes, but especially to the physical ones occurred, as well as for learning the measures regarding lifestyle changes and for adopting an appropriate behaviour with the purpose to improve the prognosis both in the short and long term. Thus, a complete cardiovascular recovery program is strongly recommended for all cardiac patients undergoing complex surgery, including for those with intracardiac devices. Determining the effort capacity after the surgical intervention ensures the premise of a satisfactory result, with the improvement of the quality of life.

\section{CASE PRESENTATION}

We present the case of a 44 years old patient, admitted in the Cardiovascular Recovery Clinic for the beginning of the second phase of the cardiovascular recovery program, being symptomatic through joint pain in the left scapulohumeral joint and marked fatigue.

\section{History}

The onset of cardiovascular pathology took place in 2000, at the age of 25 , when the patient was diagnosed with bicuspid aortic valve, a mechanical prosthesis (Edwards Mira prosthesis no. 19) being implanted during the same year. In evolution, to the personal pathological history we can add the essential blood pressure grade 3 (maximum blood pressure $185 \mathrm{mmHg}$ ) at the age of 37, for which it was recommended to initiate medical therapy (double association of conversion enzyme inhibitor and calcium blocker) with the remission of symptoms and normalization of the blood pressure profile. In September 2018, the patient comes to the Emergency Institute for Cardiovascular Diseases and Transplant Târgu Mures where surgical intervention for a prosthesis mismatch is performed, within the same open heart surgery annuloplasty of the aortic ring with pericardial patch, aortocoronary bypass with autologous reversed saphenous venous grafting on the right coronary artery and permanent electrical cardiac stimulation type VVI are performed. Currently, the patient goes to the Cardiovascular Recovery Clinic for the initiation of phase II of the cardiac recovery program, accusing scapulohumeral arthralgia and marked fatigue (home treatment with Amlodipine 5 mg/day, Acenocoumarol 4 mg according to the scheme, Spironolactone/ Furosemide 50/20 mg / day).

His father died at the age of 67 , following an acute myocardial infarction and the mother, aged 79 is known with thyroid disease. Among the personal pathological history, besides those mentioned above, he has a left groin hernia operated at the age of 40

The patient is retired due to illness (formerly a worker at a telecommunications company) and denies smoking, chronic ethanol consumption and excess of coffee/ energizing drinks.

\section{Clinical exam}

The clinical examination reveals the following pathological aspects:

- overweight (waist $170 \mathrm{~cm}$, weight $102 \mathrm{~kg}$, abdominal perimeter $119 \mathrm{~cm}$, body mass index $27.1 \mathrm{~kg} / \mathrm{m} 2$ );

- skin: pale, median poststernotomy scar, left thigh middle face scar, left groin scar;

- Cardiovascular system: blood pressure 130/80 mmHg, heart rate 77 beats/ minute, systolic murmur stage $\mathrm{V} / \mathrm{VI}$, maximal in the aortic point, with 


\section{INTERNAL}

\section{Clinical cases}

irradiation in both carotid arteries, aortic prosthesis click.

Considering the anamnestic information obtained and the clinical pathological aspects, we can say that we are in front of a patient with a significant cardiovascular pathology for his age (valvular prosthesis, permanent electrical cardiac stimulation and aortocoronary bypass), in case of whom special attention must be given to accentuated stress fatigue lately, to the anemic syndrome or to the excessive stress not correlated with the peacemaker parameters as there may be causes that need to be further explored.

\section{Paraclinical investigations}

Considering the anamnestic and clinical details obtained, the following paraclinical investigations were recommended:

1. Biological tests:

The blood count (CBC) objectified the presence of anemia ( $\mathrm{Hb} 10.8 \mathrm{~g} \%$, Ht 32\%), without other changes of the other cell lines. The biochemical balance collected upon admission showed a lipid profile within normal limits (under hypolipidemic medication at home), normal liver enzymes, pathological ionogram (Serum Iron $21.4 \mathrm{~g}$, the rest of electrolytes within normal limits).

2. Electrocardiogram:

By analysing the electrocardiographic route, we found the presence of stimulated ventricular rhythm 60/minute. (Fig.1)

3. Echocardiography:

Cardiac ultrasound found the presence of the mechanical prosthesis in the normofunctional aortic position, mitral regurgitation grade II, pulmonary regurgitation grade $\mathrm{I}$, tricuspid regurgitation grade I, stimulation probe present in the right cavities, left ventricle and diastolic diameter (LVED 47mm) with slight concentric hypertrophy, with normal kinetics (ejection fraction of the left ventricle 71\%) (Fig. 2,3,4)

4. Abdominal ultrasound:

- liver with moderate reflectogenic, homogeneous structure, of normal size

- normal cholecyst, without other changes regarding the portal vein, inferior vena cava or main bile duct.

- spleen, both kidneys, pancreas, prostate - without pathological changes

5. Monitoring of the electrocardiogram for 24 hours (HOLTER EKG)

When monitoring the electrocardiogram for 24 hours, the presence of stimulated ventricular rhythm throughout the recording period was found, with an average heart rate of 68 beats/minute (maximum of 98 beats/minute). Rare ventricular and supraventricular 


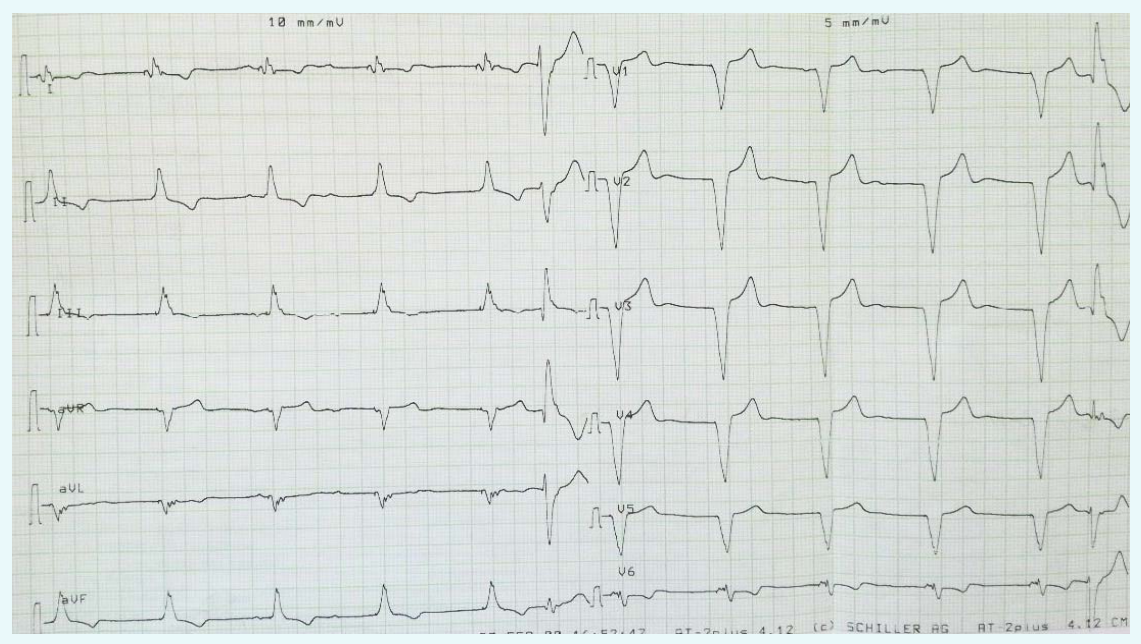

Figure 1. Electrocardiogram

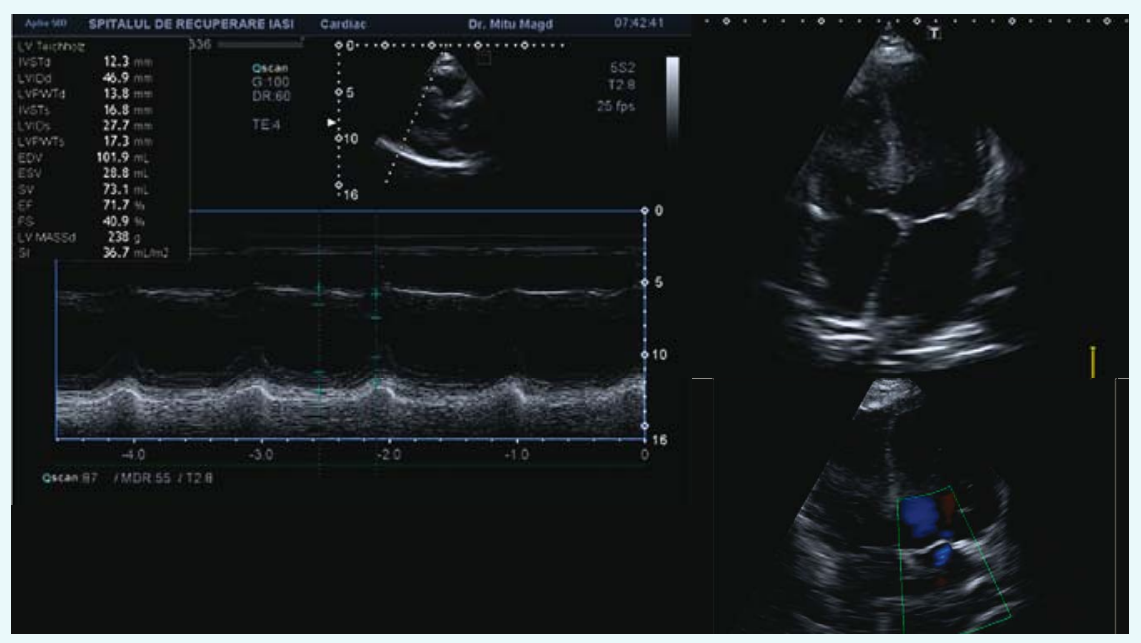

Figure 2. Echocardiography

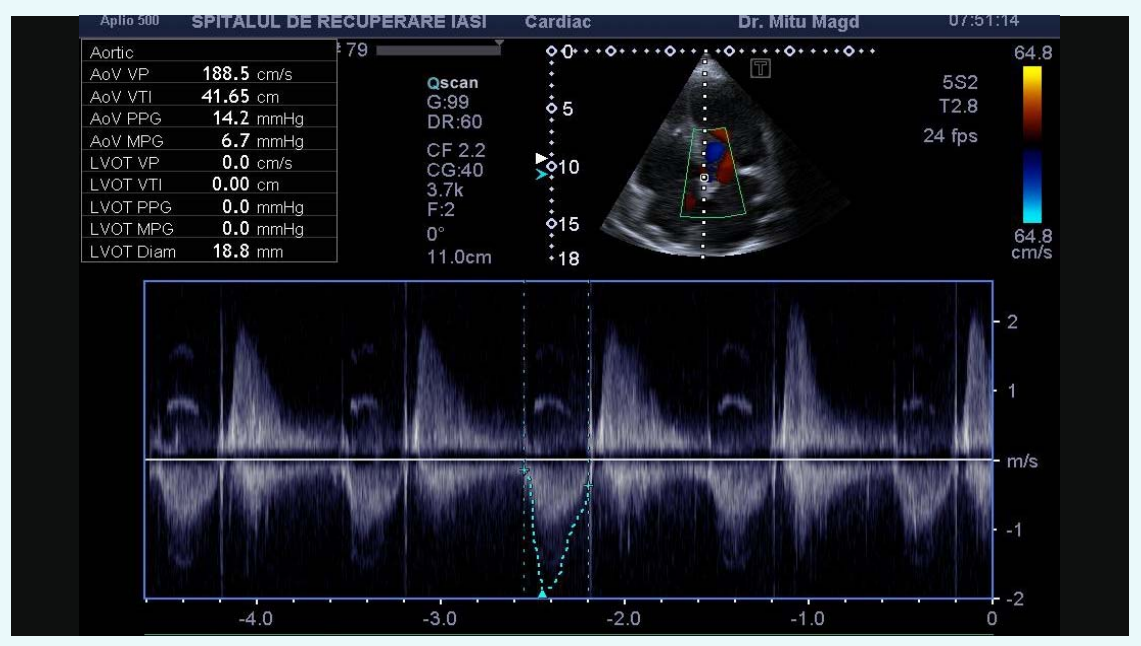

Figure 3. Echocardiography 


\section{INTERNAL}

\section{Clinical cases}

extrasystoles and no pauses over 2 seconds or malignant ventricular arrhythmias were noted. (Fig. 5).

6. Cardiopulmonary stress test:

The stress test was performed on the cycloergometer, with the progressive increase of the exercise power by $10 \mathrm{~W} /$ minute, starting from the basal level of $10 \mathrm{~W}$ until reaching the maximum level (respiratory exchange rate RER $>1$ ) or reaching the maximum predicted value for at least one of the following parameters: VO2, exercise intensity (W), heart rate, maximum voluntary ventilation, or up to the limitation caused by dyspnea or significant muscular fatigue. Continuous monitoring of the electrocardiogram, respiratory gases, respiratory volumes as well as flow rates and serial monitoring of blood pressure at intervals of 2 minutes were performed. The stress test showed the following results:

- Maximum oxygen level: a maximum value of $87 \mathrm{~W}$ of stress level was reached $(38 \%$ of the maximum predicted value); the test was stopped before reaching the anaerobic threshold, under the conditions of the significant decrease of blood pressure.

- Oxygen consumption: maximum value of $1122 \mathrm{ml} / \mathrm{minute}(42 \%$ of the maximum predicted value); this normalized value for body mass was of $13.5 \mathrm{ml} / \mathrm{kg} / \mathrm{min}$ suggestive for a moderate - severe functional alteration (Weber class C).

- Anaerobic threshold - not reached.

- Respiratory exchange rate (RER = VCO2/V02) recorded a value of 0.93 when reaching the maximum value of the physical exercise

- Heart rate response to exercise - heart rate had a rest value of 60 beats/ minute, keeping this value up to a $70 \mathrm{~W}$ level of effort intensity and reaching a maximum value of 66 beats/minute ( $38 \%$ of maximum predicted value)

- Blood pressure response to effort - it had a baseline value of $120 / 70 \mathrm{mmHg}$, during the test decreasing to $100 / 60$ $\mathrm{mmHg}$

- Electrocardiogram: no significant changes compared to rest recording

Conclusions: cardiopulmonary testing shows a moderate - severe alteration of functional effort capacity (Weber C class). The test was stopped before reaching the anaerobic threshold, under the conditions of the significant decrease of the blood pressure value (Fig. 6-9).

\section{Physical training:}

- The patient clinically tolerated the kinetotherapy sessions in phase 2 of the 


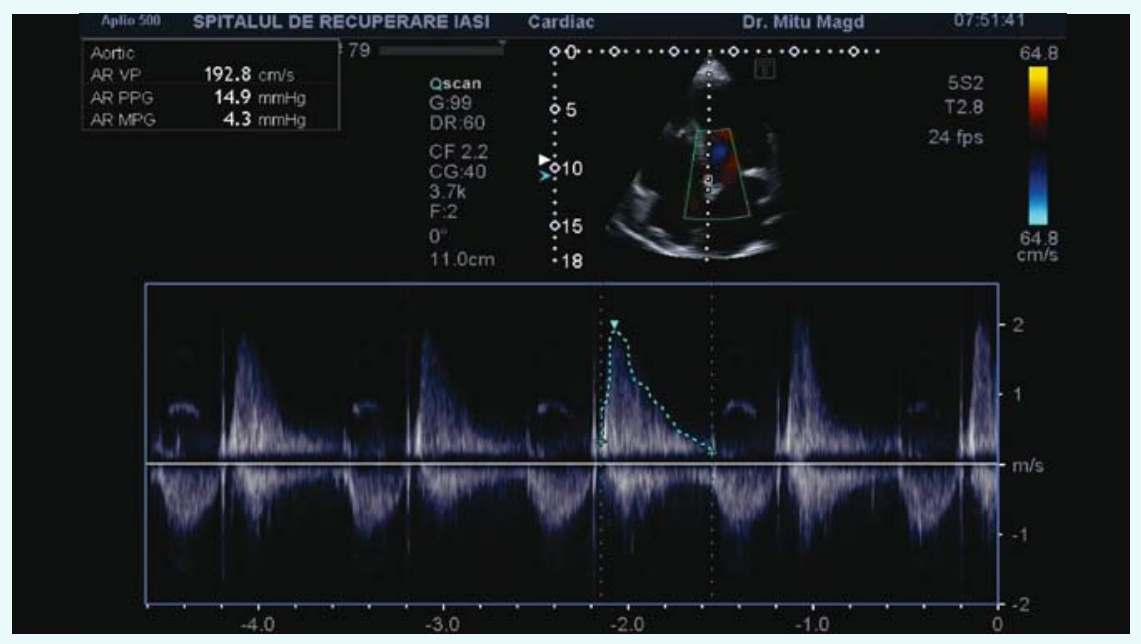

Figure 4. Echocardiography

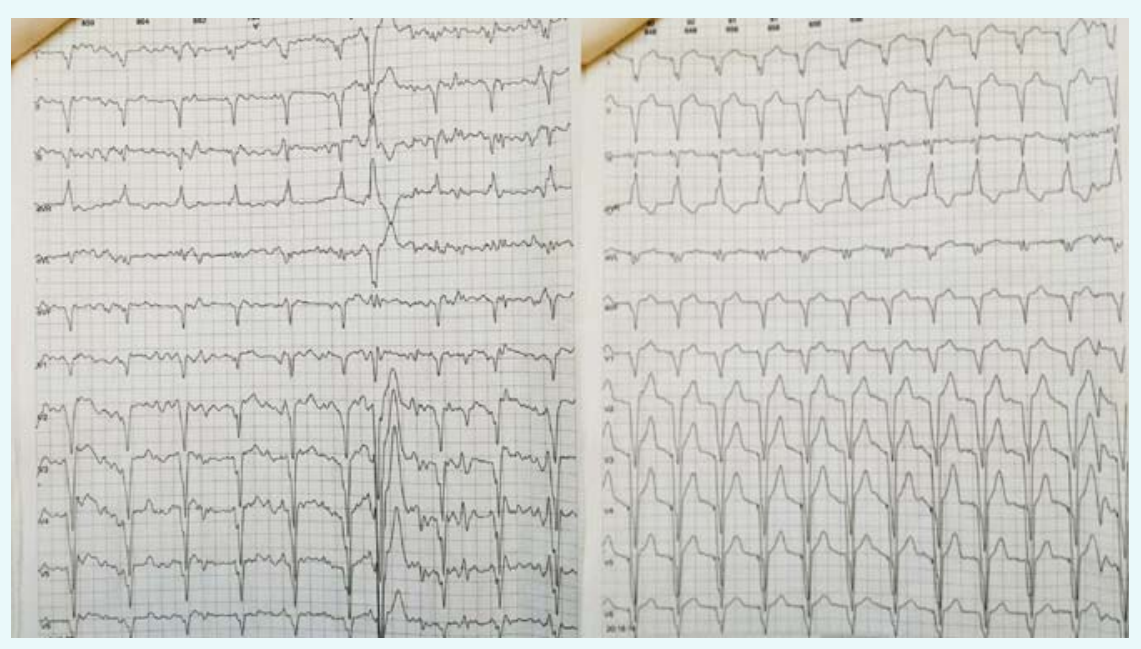

Figure 5. HOLTER EKG
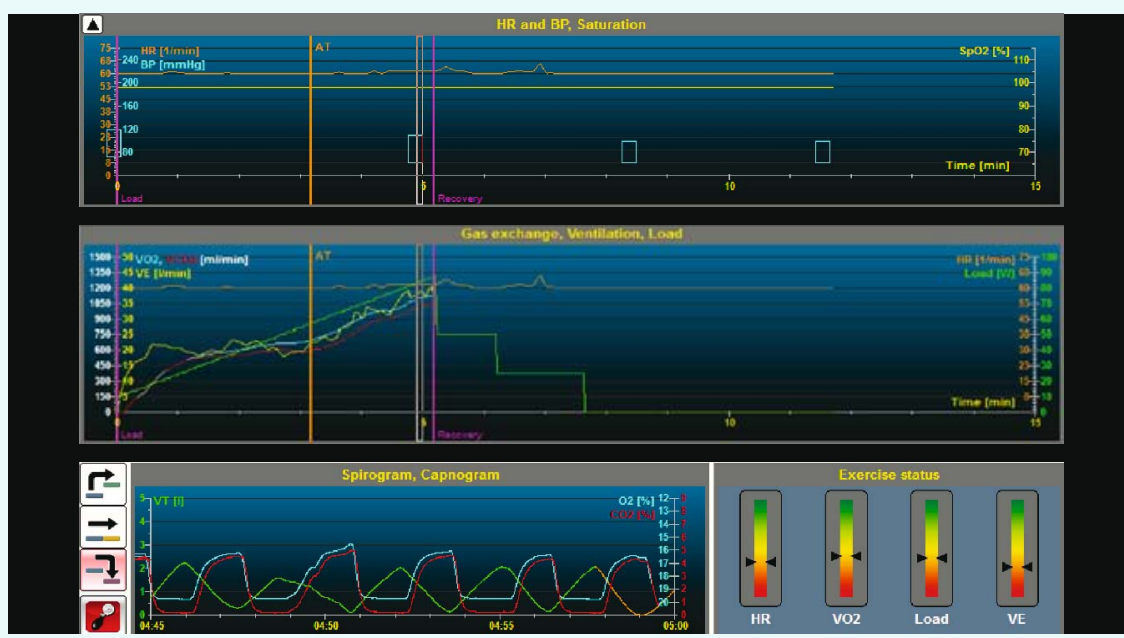

Figure 6. Parameters during the stress test 


\section{INTERNAL}

\section{Clinical cases}

cardiovascular recovery program;

- monitoring during physical activity showed the decrease of blood pressure by approximately $10-20 \mathrm{mmHg}$ compared to resting status (maximum intensity reached $25 \mathrm{~W}$ );

- stepper: maximum 80 steps (maximum heart rate $75 /$ minute)

BIOFORCE: series of exercises of 10 repetitions

At the same intensity, the physical effort using the stepper (which does not use the muscles of the upper limbs and of the chest) was well tolerated, with an increase in heart rate and blood pressure at normal parameters during exercise. This led to the continuation of physiotherapy with the avoidance of upper limb musculature due to the possible inhibition of the pacemaker caused by the position of the piezoelectric crystal.

\section{Differential diagnosis:}

Differential diagnosis of the anemic syndrome:

- Increased iron losses:

$\rightarrow$ Gastrointestinal bleeding . gastroduodenal ulcer, haemorrhagic gastritis, haemorrhoids, transhiatal gastric hernia, gastric/esophageal varices, neoplasms, ulcerative colitis

$\rightarrow$ Genitourinary bleeding: excessive menstrual loss, hematuria, hemoglobinuria $\rightarrow$ Respiratory apparatus bleeding: recurrent haemoptysis, repeated epistaxis, pulmonary hemosiderosis and/or Goodpasture syndrome

$\rightarrow$ Other losses: Rendu-Osler hereditary telangiectasia, angiodysplasia, haemostasis disorders, blood donation, intestinal parasites

- Insufficient iron intake: inadequate diet (diets high in cereals, poor in meat, in elderly and poor), alcoholism, malabsorption, hydrochloride, resected stomach, celiac disease, Pica syndrome

- Increased iron needs: growth period

- Unknown (idiopathic) causes

\section{Positive diagnosis}

1. Cardiovascular recovery

2. Prosthetic mechanical valve in aortic position

3. Aortocoronarian bypass - right coronary artery

4. Permanent electric cardiac stimulation VVI

5. Chronic heart failure class II NYHA and preserved ejection fraction

6. Essential hypertension grade 3 very high risk

7. Ferriprive anemia

8. Chronic oral anticoagulation

9. Aortic mechanical valve dysfunction caused by pannus

10. Second degree atrioventricular block Mobitz type II 


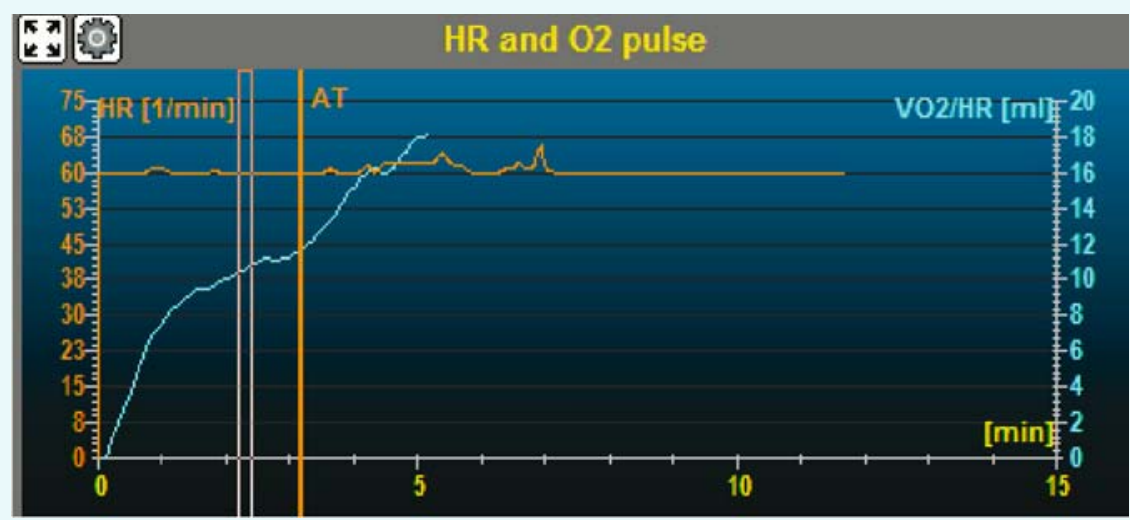

Figure 7. Hearth rate and oxigen volume

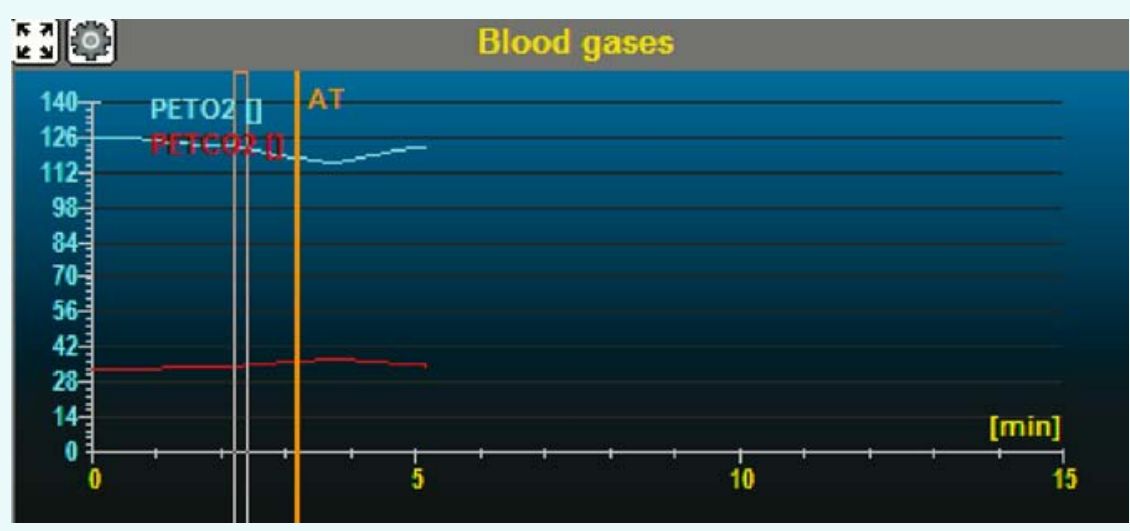

Figure 8. Blood pressure during the stress test

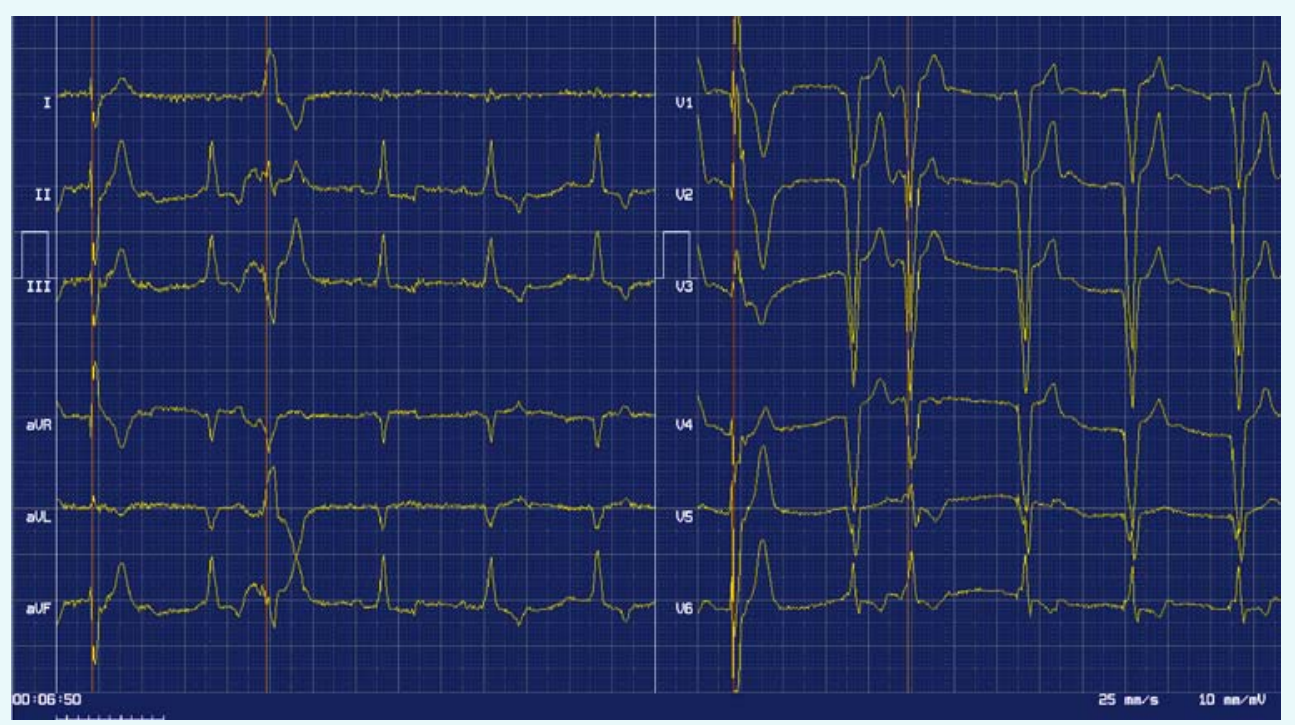

Figure 9. Electrocardiogram during the stress test 


\section{INTERNAL}

\section{Clinical cases}

11. Mild mitral regurgitation

12. Mild tricuspid regurgitation

13. Hepatic steatosis

\section{Treatment}

During hospitalization, the patient complied with the lifestyle changes given at admission (low sodium and low lipid diet, avoiding the fats of animal origin, adequate hydration, respecting the physiokinotherapy recommendations - reaching the targets indicated by the cardiopulmonary stress test) and followed treatment with Amlodipine $5 \mathrm{mg}$ daily, Spironolactone $25 \mathrm{mg}$ daily, Atorvastatin $20 \mathrm{mg}$ daily and Acenocoumarol according to the scheme. When the patient was discharged, recommendations were made regarding lifesyle changes and medication:

Diet and lifestyle:

- low sodium, low lipid diet, avoiding animal fats,

- aerobic physical effort within the tolerability limit, avoiding psychoemotional stress or extreme temperatures,

- adequate hydration (minimum 2 litres of water daily),

- the periodic control of the INR and the adjustment of the scheme according to the therapeutic limits (optimal INR 2.53.5),

- continuation of physical training at home,

- periodic cardiological control, stimulator control,
- periodic monitoring of blood pressure and heart rate at home and in primary care,

- during the anticoagulant treatment, intramuscular or subcutaneous injections are prohibited, only intravenous ones are allowed.

Medication:

Amlodipin 5 mg/day, Spironolactone 25 $\mathrm{mg} / \mathrm{day}$, Atorvastatin $20 \mathrm{mg}$ daily, Acenocoumarol according to the scheme, iron supplements.

\section{Evolution}

During hospitalization, the initial symptoms improved under the use of medication and blood pressure profile, the biological parameters and the hemodynamic ones remained within normal limits.

The patient attended physiotherapy sessions reaching the targets suggested by the cardiopulmonary stress test, with both immediate and long-term benefits, thus ensuring a quality of life corresponding to a young patient of only 44 years old.

\section{Prognosis}

- Quo ad vitam: good

- Quo ad function: good (within the limits imposed by complex pathology)

- Quo ad sanationam: reserved

\section{DISCUSSIONS}

The inclusion of patients in the cardiovascular recovery programs (which includes 3 phases) is part of their optimal management which 
allows the insurance of an adequate quality of life. An important aspect is the stratification of the risk of each case separately. Thus, based on the anamnestic and clinico-paraclinical details presented above, our patient is in the intermediate risk class. ${ }^{1,3}$

In the cardiopulmonary testing of pacemaker carriers, special attention should be paid to two aspects: - evaluation of the stimulation parameters for effort (Heart Rate - HR) during the test in the case of the stimulators without effort adaptation, HR during the test in the case of stimulators with the adaptation to effort, evaluation of response to effort in case of patients undergoing cardiac resynchronization therapy and - diagnosis of exerciseinduced arrhythmias (atrial fibrillation, ventricular extrasystoles, ventricular tachycardia and identification of arrhythmias in patients with ICD (infection caused by Clostridium difficile)). In case of a pacemaker, without adapting the effort HR, frequency will not increase in case of effort so that the patient requires continuous supervision during the cardiopulmonary stress test, with the risk of orthostatic hypotension, syncope or even cardiac failure. If in these patients the heart rate increases during the test, then the presence of the congenital atrioventricular block or the presence of ischemic etiology is suspected. ${ }^{2,4,5}$

\section{CONCLUSIONS}

Going through an effective recovery program, adapted and personalized to each patient, ensures an adequate level of life quality. Chronotropic incompetence or the presence of intracardiac devices not programmed according to the patient's lifestyle prevents a favourable outcome, with the persistence of a submaximal functional capacity. Within cardiopulmonary testing in patients with pacemaker special regards should be paid towards: parameters assessment during effort (heart rate during the test in pacemakers without adaptation to exercise, heart rate during the test in pacemakers with adaptation to exercise, evaluation of the effort response in patients undergoing resynchronization therapy) and diagnosis of exercise-induced arrhythmia (atrial fibrillation, ventricular extrasystoles, ventricular tachycardia, as well as identification of arrhythmias in patients with implantable cardioverter defibrillator).

\section{PARTICULARITY OF THE CASE}

- Patient with a complex cardiovascular pathology (hypertensive, mechanically prosthetic valve, in need of cardiac stimulation and with aortocoronary bypass), young (44 years old)

- A cardiac stimulated patient undergoing a cardiopulmonary stress test, the conditions for performing the test are important in order to obtain real results of the functional capacity due to the position of the piezoelectric crystal and the immobilization of the limbs during the test with the cycloergometer, it is recommended to test the patient using the rolling mat.

\section{Bibliography:}

1. Apetrei E. Cardiologie Clinica. Editura Medicală Callistro, 2005, p 1157-1172;

2. Brubaker PH, Kitzman DW. Chronotropic incompetence: Causes, consequences, and management. Circulation 2011;123:1010-20;

3. Kitzman DW, Groban L. Exercise intolerance. Cardiol Clin 2011;29:461-77;

4. Tse HF, Siu CW, Lee $K L$, Fan $K$, Chan HW, Tang MO, Tsang $V$, Lee SW, Lau CP. The incremental benefit of rateadaptive pacing on exercise performance during cardiac resynchronization therapy. J Am Coll Cardiol. 2005 Dec 20;46(12):2292-7;

5. Van Hemel NM, Holwerda KJ, Slegers PC, Spierenburg HA, Timmermans AA, Meeder JG, et al. The contribution of rate adaptive pacing with single or dual sensors to health -related quality of life. Europace 2007;9:233-8. 